\title{
Japan pledges new aid to Minamata victims
}

Tokyo. After decades of foot-dragging, the Japanese government has at last come forward with a scheme to compensate thousands of victims who were poisoned with mercury-contaminated seafood in the 1950 s and 1960s in one of the world's worst cases of industrial pollution.

Last week, the country's three ruling coalition parties - the Liberal Democratic Party, the Social Democratic Party of Japan and the New Party Sakigake - mapped out a plan that will loosen the government's criteria for designating sufferers of so-called Minamata disease.

The plan will also provide financial assistance to the company responsible for the pollution, Chisso Corporation, to help it pay the huge amount of compensation - estimated to be at least $¥ 25$ billion (US $\$ 300$ million) - for newly acknowledged victims, many of whom are already dead.

But the government has not accepted any legal responsibility for the disaster. Indeed, its lengthy court battles with Minamata victims have highlighted the lack of redress under Japan's legal system for victims of disasters in which the government has played a role.

Minamata disease is a crippling disorder of the central nervous system that causes victims to lose control of their arms, legs, speech and eyesight. The first such case was recognized in 1956 in the small fishing village of Minamata in southern Japan, and as early as 1957 , researchers at the nearby Kumamoto University had linked the disease to traces of mercury found in the brains of dead victims.

But these conclusions were ignored by both the central and local governments. It was not until 11 years later that the government ordered Chisso to stop dumping mercury-laden sludge into Minamata Bay. By that time, thousands of people throughout Japan's southern island of Kyushu had been poisoned with mercury-contaminated seafood from the Minamata area.

The government and Chisso Corporation have recognized about 3,000 severely affected victims, who have each been paid large amounts of compensation. But about 10,000 people with milder symptoms have not been recognized as victims, and many of these have been fighting the government in the courts for recognition and compensation.

There have been six district court rulings over the past decades, three of which have held the government responsible. But the government has appealed against each decision, and, as a result of the snail's pace at which such cases are treated by Japan's legal system, decisions at a higher court level have yet to be made.

Under the old criteria for acknowledging victims of Minamata disease, these were only officially accepted as such by the government if they suffered severe disabilities such as dysfunction of the motor nerves and narrowed vision. By contrast, under the coalition government's scheme adopted last

\section{IMAGE UNAVAILABLE FOR COPYRIGHT REASONS}

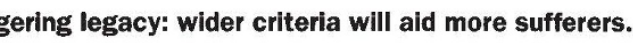

week, victims will now be recognized if they suffer any form of paralysis of the central nervous system that can be attributed to mercury poisoning, and if they live (or lived) in the contaminated area.

The government's decision to relax the criteria has resulted from the reduced influence of the Liberal Democratic Party (LDP), which ruled Japan continuously for 38 years until 1993. The LDP and the Environment Agency, which has jurisdiction over the case, steadfastly refused to recognize more victims. But the two other parties in the new coalition government, which are keen to resolve the case, managed to persuade the LDP to make concessions.

The Minamata case is by no means exceptional. The day after the prime minister, Tomiichi Murayama, announced the coalition's Minamata plan, the Supreme Court absolved the government of all blame

in a 20 -year court battle over another medical disaster involving the drug chloroquine.

Introduced to Japan in 1955, initially as an antimalaria drug, chloroquine is believed to have caused impaired vision in about 1,300 patients. It was widely used in Japan

$\sum$ throughout the 1960 s for treatment

总 of rheumatism, epilepsy and kidney

inflammation, even though a British

medical journal reported in 1959

that the drug is able to cause damage to the retina.

In 1965, the head of the Ministry of

Health and Welfare's pharmaceutical department stopped taking the drug for his own rheumatism after learning of its potential side-effects. But the ministry did not order manufacturers to include a warning about possible side-effects until 1969 , and did not acknowledge that the severity of the side-effects outweighed its effectiveness in treating kidney inflammation until 1976.

Between 1975 and 1978, many patients with impaired vision sought redress for their injury in the courts. In 1982, the Tokyo District court ruled in their favour and ordered the government, pharmaceutical companies and hospitals to pay $¥ 3.6$ billion in compensation.

This decision was, however, overruled in 1988 by the Tokyo High Court, which absolved the government of blame, and said that only the pharmaceutical companies should pay the compensation - a ruling confirmed by the Supreme Court last week.

Critics of this latest ruling include Gunshiro Yokozawa, who heads a group of chloroquine victims. "As one of the victims, I feel deep anger," he is reported to have said. "This judgement proves that the judicial system is on the side of the government".

David Swinbanks

\section{Technology office heads for reprieve}

Washington. The US Office of Technology Assessment (OTA), the congressional body that provides advice to legislators on science and technology issues, won an unexpected reprieve last week from the House of Representatives.

An amendment put forward by Amo Houghton (Republican, New York) to an appropriations bill designed to save the agency but cut its budget from $\$ 22$ million to $\$ 15$ million and merge it into the larger Congressional Research Office was passed in a surprise vote by 220 to 204 .

The result was greeted with jubilation at the OTA, where many staff had been expecting the office to close after appropriations subcommittees in both House and Senate had said that they wanted to elimi- nate it (see Nature 373, 270; 1995).

Indeed, Ron Packard (Republican, California), chairman of the House subcommittee, said after the vote that he would still try to have the OTA's whole budget eliminated when the Senate and House appropriations bills are reconciled in conference.

But the House vote now makes it likely that the OTA will also win support in the Senate, where its work is better known, and only a few Republican defections are needed to win a majority for any move to keep it alive. In the House, 48 Republicans joined Democrats in supporting the OTA, convinced by the argument that Congress needs the office to help it legislate sensibly on complex scientific and technological issues.

Colin Macilwain 